Earth Science India, eISSN: $0974-8350$

Vol. 7 (IV), October, 2014, pp. 90 - 105

http://www.earthscienceindia.info/

\title{
Trends in Rainfall and Temperature Patterns over North East India
}

\author{
Markand Oza and C. M. Kishtawal \\ Space Applications Centre (ISRO), Ahmedabad- 380015, India \\ Email: markand@sac.isro.gov.in
}

\begin{abstract}
The present study examines long-term changes and short-term fluctuations in Indian Summer Monsoon (ISM) rainfall and temperature over North East India (NEI) in Eastern Himalayan region. Rainfall data for period 1871-2012 and temperature data for the period 1901 - 2007 were used in this study. Long-term behavior was assessed using parametric linear trend model as well as with the non-parametric Mann-Kendall rank statistic. The short-term fluctuations were studied by applying Cramer's t-test for the 11year running means. The striking features are the varied epochs of above- and belownormal ISM rainfall at different spatial scales and temperature in various seasons in this region. The detailed analysis of data over North East India indicated (i) steep decreasing trend in ISM rainfall; (ii) increasing behaviour of maximum temperature; and (iii) decade of $1960-70$ as a time point of change.
\end{abstract}

Keywords: Time series; Trend; Statistical tests; Temperature; Rainfall

\section{Introduction}

Climate is one of the key components in the earth system. There are many variables such as temperature, rainfall, albedo, atmospheric pressure, humidity that constitute weather and climate. Climate is usually defined as the average weather. In broad sense it is the statistical description in terms of the mean and variability of relevant quantities over a period of time ranging from months to thousands or millions of years (IPCC, 2008).

There is mounting evidence that the global climate is changing. Considerable amount of change is attributed due to human activity. Human activities that could possibly change the climate are as a result of emission of gases in the atmosphere, industrial activities, urbanisation, environmental pollution, creation of dams and lakes, conversion of grassland or forest for agricultural activities (Piechota and Garbrecht, 2006).

The analysis of long-term changes in climatic variables is a fundamental task in studies on climate change detection. The understanding of past and recent climate change has received considerable attention through improvements and extensions of numerous datasets and more sophisticated data analyses across the globe. Several researchers studied variability and trends in weather variables across the world (Abaje et al., 2012; Tabari et al., 2011; Deka et al., 2009; Klein Tank and Können 2003; Kadiolgu, 1997). Over India, one of the early studies for detecting trends in weather patterns was by Pramanik and 
Jagannathan (1954). Following this work, many researchers have analysed patterns to identify trends in weather variables over India (see Kumar and Hingane 1988; Kumar et al., 1994; Pant and Kumar 1997; Kothawale and Kumar, 2005, Arora et al., 2005, Ganguly and Iyer, 2009; Dhorde et al., 2009; Wagholikar et al., 2014). Most efforts in climate change studies have focused on the global and regional scale. However, climate change studies do not exclude local trends in a small-scale area. In fact, local and regional scale analysis is more relevant to devise specific development and adaptation plans to mitigate negative effects of climate change.

\section{Objective, Study Area and Data Used}

The primary aim of the present work was to understand the variations in Indian Summer Monsoon (ISM) rainfall, maximum temperature (TX) and minimum temperature (TN) by means of parametric as well as non-parametric statistical techniques. The study was carried out in North East India (NEI) which is situated in Eastern Himalayan region. It is bounded within $87^{\circ} 50^{\prime}$ to $96^{\circ} 30^{\prime}$ E Longitude and $21^{\circ} 08^{\prime}$ to $30^{\circ} 12^{\prime} \mathrm{N}$ Latitude. This is a region of high rainfall and includes Brahmaputra Basin. NEI has distinct precipitation and drainage patterns, unique physiographic and hydrogeomorphic regimes. Climate of NEI is distinct from that of the rest of India due to special features like orography, alternating pressure cells over NEI and Bay of Bengal and the local mountain and valley winds. The extensive water bodies and forest areas add to its climate individuality.

NEI is covered by meteorological subdivisions (MSBD) no. 2 (Arunachal Pradesh), 3 (Assam and Meghalaya), 4 (Nagaland, Manipur, Mizoram and Tripura) and 5 (subHimalayan West Bengal and Sikkim) defined by India Meteorological Department (IMD). This is shown in Fig. 1. Rainfall data for period $1871-2010$ and temperature data for the period $1901-2007$ used in this study were taken from www.tropmet.res.in.

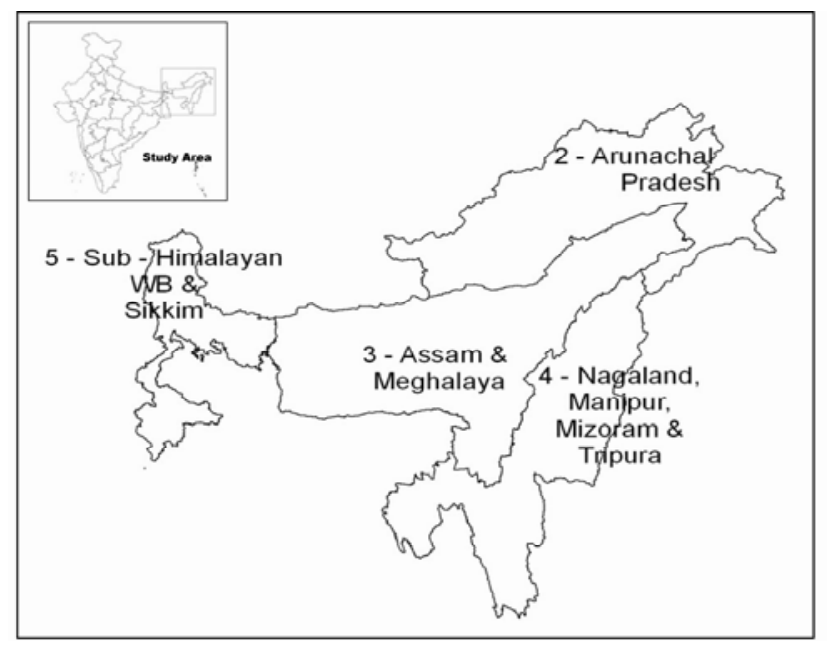

Fig.1: Location map of the study area: North East India with boundaries of meteorological subdivisions of India. 
Open access e-Journal

Earth Science India, eISSN: $0974-8350$

Vol. 7 (IV), October, 2014, pp. 90 - 105

http://www.earthscienceindia.info/

\section{Methodology}

The purpose of a trend analysis/test is to determine general (or overall) behaviour of the variable under consideration as a function of time. Such a method of data analysis confirms the presence of suspected trends, presents unknown trends and assesses the detected trends. Several methods of estimating linear trends and their significance are used in climatological studies.

In applications of statistics to climatology for analysing trends, both parametric and nonparametric methods are widely used. Parametric trend tests are regarded to be more powerful than the non-parametric ones when the data are normally distributed, independent and have homogeneous variance (Hamed and Rao, 1998). For detecting trend in a variable, the data series is smoothed. In the present study, 11-year moving average (Kripalani and Kulkarni, 1996) was applied. Basically, it performs low pass filtering in time domain. By doing this smoothing, the year-to-year variations get suppressed and dominant behavior, if any, emerges. If there is increasing trend in the climatic series, then the slope coefficient should be positive and statistically significant. Conversely, for decreasing trend in behavior of a variable the slope value should be negative.

For detecting trend in the smoothed data series, parametric and non-parametric approaches were employed. In the present study, 5\% level is chosen to determine if a trend is significantly different from zero.

\section{Method of Least Squares:}

In parametric approach, a trend of the form $\mathrm{y}=\mathrm{m}^{*} \mathrm{x}+\mathrm{c}$, where $\mathrm{y}$ is the dependent variable (e.g. rainfall or temp) and $\mathrm{x}$ is independent variable (time), was fitted. Probably the most common approach to estimate magnitude of trend (i.e. slope $m$ ) is by method of least squares. For $\mathrm{n}$ pairs of data $\left(\mathrm{x}_{1}, \mathrm{y}_{1}\right),\left(\mathrm{x}_{2}, \mathrm{y}_{2}\right), \ldots\left(\mathrm{x}_{\mathrm{n}}, \mathrm{y}_{\mathrm{n}}\right)$, the estimates of $\mathrm{m}$ and $\mathrm{c}$ are obtained as

$$
\begin{array}{ll}
\mathrm{m}= & {\left[\mathrm{n}\left(\Sigma \mathrm{xy}-\left(\sum \mathrm{x}\right)\left(\sum \mathrm{y}\right)\right] /\left[\mathrm{n}\left(\sum \mathrm{x}^{2}\right)-\left(\sum \mathrm{x}\right)^{2}\right]\right.} \\
\mathrm{c}= & {\left[\left(\sum \mathrm{y}\right)^{*}\left(\Sigma \mathrm{x}^{2}\right)-\left(\sum \mathrm{x}\right)(\Sigma \mathrm{xy})\right] /\left[\mathrm{n}\left(\Sigma \mathrm{x}^{2}\right)-(\Sigma \mathrm{x})^{2}\right]}
\end{array}
$$

Statistical significance of coefficients is assessed by applying t-test. The parameters of the fit such as coefficients, their standard errors, $\mathrm{R}^{2}$ value, F-statistic were also computed.

\section{Mann-Kendall Rank Test:}

Non-parametric Mann-Kendall method is a distribution-free method, more resistant to outliers, can usually be used with gross data errors, and can deal with the missing data values unlike the parametric method (Wilcox, 1998). Mann-Kendall rank test is widely 
used in environmental monitoring for its simplicity and the focus on pair-wise slopes (Gibbons and Coleman, 2001). However, non-parametric methods are fraught with more uncertainty in the statistical estimates than the parametric method (Alexander et al., 2006). In the present study, we have used Mann-Kendall rank test which is based on order (or rank) rather than magnitude of measurement. This statistic was used to determine the possible existence of any significant trend in the collected data over a period of time. However, it indicates only the direction and the significance of the trend and cannot quantify the trend. This test was found to be useful and widely used for detecting trends in climate and environment sciences (Sneyers, 1990; Kadiolgu, 1997).

The Mann-Kendall rank statistics (MKT) is computed from

with

$$
\operatorname{MKT}=\left[\left(4 \Sigma \mathrm{n}_{\mathrm{i}} / \mathrm{N}(\mathrm{N}-1)\right]-1\right.
$$

$$
\operatorname{var}(\mathrm{MKT})=[(4 \mathrm{~N}+10) /(9 \mathrm{~N}(\mathrm{~N}-1)]
$$

where, $\mathrm{n}_{\mathrm{i}}$ is the number of values larger than the $i^{\text {th }}$ value in the series subsequent to its position in the series of $\mathrm{N}$ values.

Notice that it is distribution-free (hence robust), positive (negative) value of $\mathrm{S}$ indicates increasing (decreasing) trend but gives only direction (not magnitude) of trend.

\section{Cramer's Tau:}

Statistical attempts to identify climatic trends frequently employ the calculation of a moving mean; a smoothing mean is utilized to smooth out many of the short-term fluctuations. The averages are examined in order to see whether these local (in temporal scale) means differ from the mean of the entire study period. The purpose of applying moving Cramer's test to the time series is to find out significant periods with abnormal averages, if any.

The formula for computing Cramer's test statistics is as follows:

The $\mathrm{t}$-statistics, $\mathrm{t}_{\mathrm{k}}$ is computed as (Abaje et al., 2012; Mirza, 1997; WMO, 1966)

$$
\mathrm{t}_{\mathrm{k}}=\mathrm{l}_{\mathrm{k}}\left[\left(\mathrm{n}(\mathrm{N}-2) /\left\{\mathrm{N}-\mathrm{n}\left(1+\mathrm{l}_{\mathrm{k}}^{2}\right)\right\}\right]^{0.5}\right.
$$

where, $l_{k}=\left(m_{k}-\mu\right) / \sigma ; \mu$ is the mean and $\sigma$ is the standard deviation of the series for the total number of years $(N)$ under investigation; $m_{k}$ is the mean for each successive $n$-year.

\section{Mann Whitney Test:}

The Mann-Whitney test is a non-parametric test for assessing the significance of a difference in central tendency of two series (Kite, 1988; Essenwanger, 1985). The test is 
Open access e-Journal

Earth Science India, eISSN: $0974-8350$

Vol. 7 (IV), October, 2014, pp. 90 - 105

http://www.earthscienceindia.info/

often viewed as the non-parametric equivalent of the Student's t-test. The null hypothesis for the test is that the two series from which samples have been drawn have equal medians or means. The alternatives are that the series do not have equal medians. In the context of testing for step change, the time of change is assumed known and the series is divided into two groups (before and after this time point) and these groups are compared.

The logic behind the Mann-Whitney (also called Wilcoxon-Mann-Whitney or ranksum test) as test is to rank the data for each condition, and then see how different the two rank totals are. If there is a systematic difference between the two conditions, then most of the high ranks will belong to one condition and most of the low ranks will belong to the other one. As a result, the rank totals will be quite different. On the other hand, if the two conditions are similar, then high and low ranks will be distributed fairly evenly between the two conditions and the rank totals will be fairly similar. The Mann-Whitney test statistic reflects the difference between the two rank totals. The smaller the difference, then it is less likely it is to have occurred by chance.

The procedure to compute the rank-sum test statistic (Hirsch et al., 1992) is as follows:

(i) Assign ranks to all the data, from 1 (smallest) to $\mathrm{N}$ (largest)

(ii) Split the data into two groups of size $m$ and $n$.

(iii)Compute a test statistic $\mathrm{S}$ as the sum of ranks of the $\mathrm{n}$ observations in the smaller group.

(iv)Compute the theoretical mean and standard deviation of $\mathrm{S}$ under $\mathrm{H}_{0}$ for the entire sample:

$$
\begin{aligned}
& \mu=\mathrm{n}(\mathrm{N}+1) / 2 \\
\sigma= & {[\mathrm{nm}(\mathrm{N}+1) / 12] }
\end{aligned}
$$

For large sample, a z-score can be used.

\section{Results}

Of many climatic variables, rainfall and temperature are perhaps the most widely used. In the present study, long time data series of more than 100 years for these two important variables over North East India were analysed.

\section{Analysis of rainfall data:}

Attempts were made to identify secular trends in rainfall data. The present study was confined to amount of rainfall during ISM moths of June to September (JJAS for short). Rainfall data for the period 1871-2012 was analysed. The rainfall data were available at MSBD level also. MSBD 2, 3, 4 and 5 form part of NEI. The study was 
conducted at these MSBDs except for MSBD 2 (for which data were not available). Trends in Indian summer monsoon rainfall for All India, NEI and MSBDs 3, 4 and 5 are reported in Table-1.

Table-1: Trends in Indian summer monsoon (JJAS) rainfall at various scales.

\begin{tabular}{|l|c|c|c|c|c|c|c|}
\hline \multirow{2}{*}{ Region } & Mean & $\begin{array}{l}\text { Standard } \\
\text { Deviation }\end{array}$ & \multicolumn{4}{|c|}{ Trend OLS Method } & \multicolumn{2}{c|}{$\begin{array}{c}\text { Mann-Kendall } \\
\text { Rank Test }\end{array}$} \\
\cline { 2 - 8 } & & & & & $\begin{array}{l}\text { Statistical } \\
\text { Significance }\end{array}$ & MKT & $\begin{array}{l}\text { Statistical } \\
\text { Significance }\end{array}$ \\
\hline All India & 848.41 & 25.27 & -0.198 & 0.055 & $\mathrm{~S}$ & -0.195 & $\mathrm{~S}$ \\
\hline NEI & 1414.80 & 39.03 & -0.455 & 0.080 & $\mathrm{~S}$ & -0.240 & $\mathrm{~S}$ \\
\hline MSBD 3 & 1510.68 & 61.95 & -0.646 & 0.130 & $\mathrm{~S}$ & -0.212 & $\mathrm{~S}$ \\
\hline MSBD 4 & 1325.43 & 69.21 & -1.144 & 0.123 & $\mathrm{~S}$ & -0.456 & $\mathrm{~S}$ \\
\hline MSBD 5 & 2002.98 & 81.19 & -0.536 & 0.180 & $\mathrm{~S}$ & -0.187 & $\mathrm{~S}$ \\
\hline
\end{tabular}

$\mathbf{S}$ - Statistically significant at $5 \%$ significance level; NS - Statistically non-significant

Basic statistics such as mean and standard deviation of smoothed series, the slope value, its standard error and statistical significance from OLS method and MKT statistic along with its statistical significance are given in Table-1. Notice that variance of MKT statistic is function of length of series which is same for all the cases and hence not reported in the table.

It is very clear from slope values and their statistical significance columns of Table 1 that there is a decreasing trend in ISM rainfall at all India level as well as in NEI. The rate of decrease is stepper by factor of more than 2 for NEI compared to all India level. Even in NEI, Eastern most MSBD 4 has most rapid decline of about $114 \mathrm{~mm} / 100$-years, central MSBD 3 has medium declining trend of about $65 \mathrm{~mm} / 100$-year and western MSBD 5 has slowest decline (but still alarming!) of about $54 \mathrm{~mm} / 100$-years during study period of 1871 to 2012.

An illustrative graph of raw and 11-year moving averaged series of JJAS rainfall is shown in Fig. 2. It can be seen that there is considerable amount of year to year variation. Besides amount of rainfall, it is of interest to study year to year variability in the amount of rainfall. It is well known that standard deviation is a measure of spread. Therefore, in the present study, year to year variability was studied using trends in 11-year moving standard deviation series. The results are given in Table-2.

It can be seen that there is increasing variability in NEI \& MSBD 3 but variability is decreasing in MSBD 5. There is no statistically significant pattern at all India and MSBD 4 level. 
Open access e-Journal

Earth Science India, eISSN: $0974-8350$

Vol. 7 (IV), October, 2014, pp. 90 - 105

http://www.earthscienceindia.info/

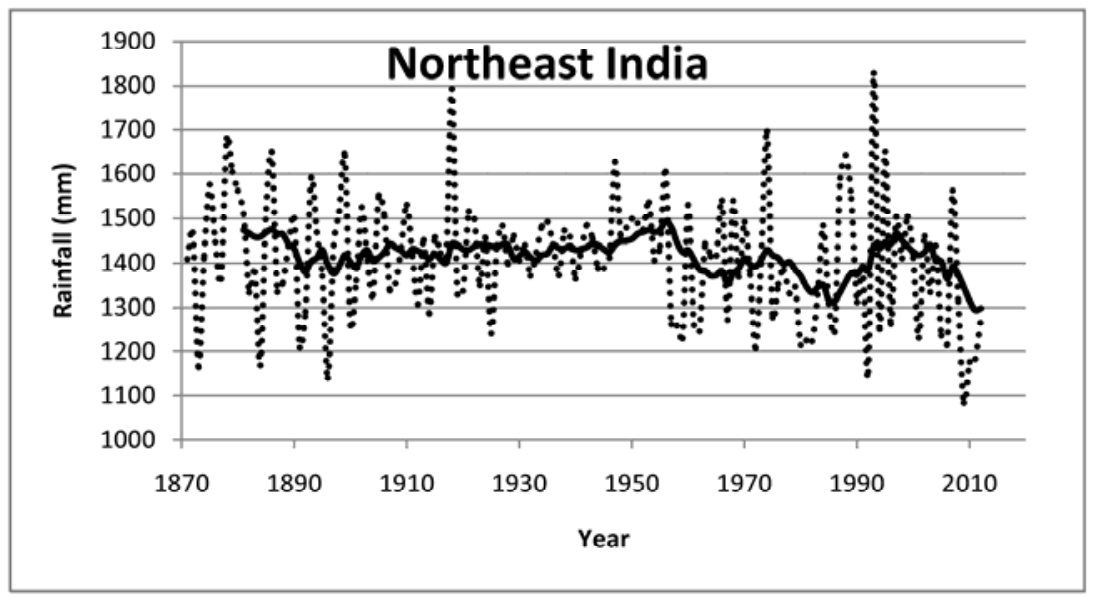

Fig. 2: Temporal pattern of JJAS rainfall for North East India (NEI) for study period (1871 -2012). Dashed line represents original series and solid line represents 11-year moving average data.

Table-2: Trends in standard deviation of Indian summer monsoon (JJAS) rainfall at various scales.

\begin{tabular}{|c|c|c|c|}
\hline \multirow[b]{2}{*}{ Region } & \multicolumn{3}{|c|}{ Trend OLS Method } \\
\hline & Slope & se(slope) & $\begin{array}{l}\text { Statistical } \\
\text { Significance }\end{array}$ \\
\hline All India & -0.004 & 0.040 & NS \\
\hline NEI & 0.193 & 0.095 & $\mathrm{~S}$ \\
\hline MSBD 3 & 0.246 & 0.113 & $\mathrm{~S}$ \\
\hline MSBD 4 & 0.053 & 0.085 & NS \\
\hline MSBD 5 & -0.412 & 0.159 & $\mathrm{~S}$ \\
\hline
\end{tabular}

S - Statistically significant at $5 \%$ significance level; NS - Statistically non-significant

To detect short term behavior within the analysis period, Cramer's tau statistic was computed and is plotted (Fig. 3). Since the length of series is long, the values beyond $+/-2$ (i.e. values beyond 2 sigma level corresponding to $5 \%$ significance level) can be considered as statistically significant. It can be seen that there is regularity of patterns. For example, closer inspection of figure 3 (a) reveals that rainfall in NEI was above long time average rainfall in early time, say upto year 90 corresponding to year $1960(1871+90=$ 1961), and dominated by below normal in recent past. Similar patterns are noticeable for MSBD 3 and 4 (Fig. 3 b \& c) with transition years being 1961 and 1971 respectively. For MSBD 5 (Fig. 3d), the transition points are at years 1931, 1991 and 2000. Also noticeable is a period of above normal rainfall during years 1990 to 2000 at these scales except MSBD 4. 


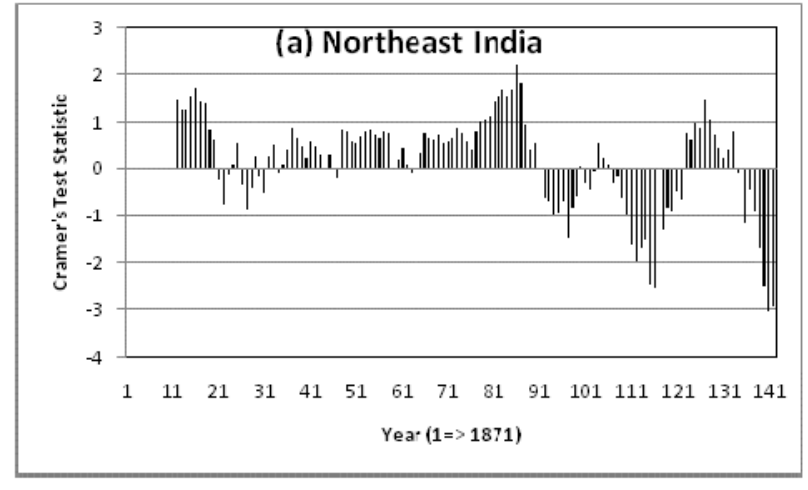

(c) MSBD 4

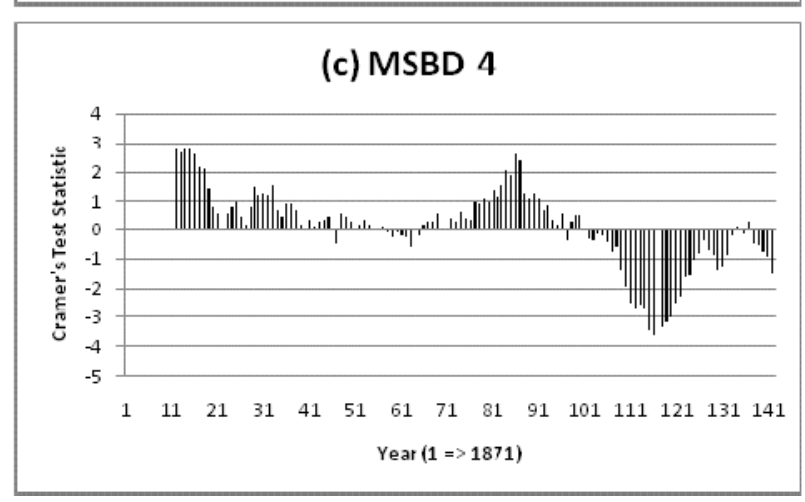

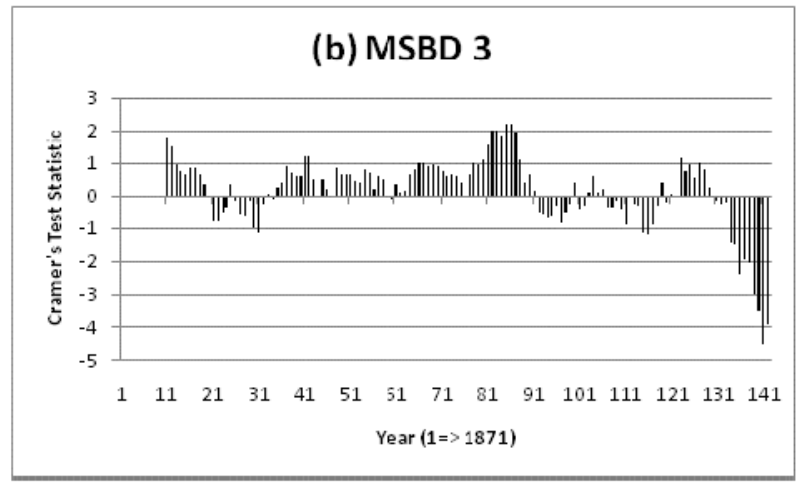

(d) MSBD 5

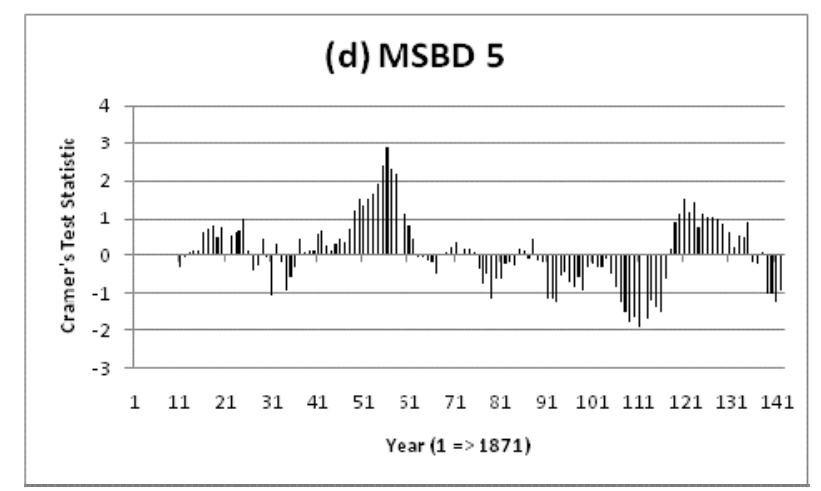

Fig. 3: Plot of Cramer's tau statistics (on y-axis) for rainfall during 1871 - 2012 for various regions, namely (a) North East India (NEI); (b) MSBD 3; (c) MSBD 4; and (d) MSBD 5.

Table-3: The Mann-Whitney test statistic (MW - U) for Indian summer monsoon at various scales.

\begin{tabular}{|l|c|c|c|}
\hline \multicolumn{1}{|c|}{ Region } & MW- U & $\mathbf{z}$ & $\begin{array}{c}\text { Statistical } \\
\text { Significance }\end{array}$ \\
\hline All India & 2920 & -1.91 & NS \\
\hline NEI & 2776 & -2.53 & - S \\
\hline MSBD 3 & 2759 & -2.61 & - S \\
\hline MSBD 4 & 2490 & -3.77 & - S \\
\hline MSBD 5 & 3167 & -0.84 & NS \\
\hline
\end{tabular}

S - Statistically significant at $5 \%$ significance level; NS - Statistically non-significant

For rainfall data, year 1965 appears to be time point from where the patterns have changed. In the present study, year 1965 was taken as a break point and statistical significance was performed. The null hypothesis is "there in no change in amount of ISM rainfall for series 
Open access e-Journal

Earth Science India, eISSN: $0974-8350$

Vol. 7 (IV), October, 2014, pp. 90 - 105

http://www.earthscienceindia.info/

(1871 -1965) and (1966 - 2012)". To ascertain this hypothesis, Mann-Whitney non-parametric test for was applied. The mean and standard deviation of sum of ranks of smaller series (1966 2012) under the null hypothesis are 3360.5 and 230.669, respectively. The values of U- statistic, the z-value and statistical significance for Indian summer monsoon rainfall at various spatial scales are given in Table-3.

Perusal of Table-3 reveals that NEI, MSBDs 3 and 4 shown definite declining rainfall regime from 1871-1965 to 1966-2012. The All India and MSBD 5 have negative z-values but are not statistically significant.

\section{Analysis of Temperature Data:}

For temperature data, attempts were made to identify secular trends in maximum and minimum temperatures. Following IMD, four seasons of India are defined as winter (Months of January-February or JF), pre-monsoon (Months of March - April - May or MAM), summer monsoon (June - July - August - September or JJAS) and post monsoon (October - November December or OND). Monthly TX and TN data for the period 1901 - 2007 over NEI available from IMD were used. The data were organized and series of TX and TN were the four seasons were generated. A graph of raw and moving averaged series of TX and TN for the four seasons is shown in Fig. 4. It can be seen that there is considerable amount of year to year variation.

Table-4: Trends in seasonal temperature data.

\begin{tabular}{|c|c|c|c|c|c|c|c|c|}
\hline \multirow{2}{*}{$\begin{array}{l}\text { Season } \\
\text { (Months) }\end{array}$} & \multirow[t]{2}{*}{ Variable } & \multirow[t]{2}{*}{ Mean } & \multirow[t]{2}{*}{$\begin{array}{l}\text { Standard } \\
\text { Deviation }\end{array}$} & \multicolumn{3}{|c|}{ Trend OLS Method } & \multicolumn{2}{|c|}{$\begin{array}{c}\text { Mann-Kendall Rank } \\
\text { Test }\end{array}$} \\
\hline & & & & Slope & se(slope) & $\begin{array}{l}\text { Statistical } \\
\text { Significance }\end{array}$ & MKT & $\begin{array}{l}\text { Statistical } \\
\text { Significance }\end{array}$ \\
\hline \multirow{2}{*}{$\begin{array}{c}\text { Winter } \\
\text { (JF) }\end{array}$} & $\mathbf{T X}$ & 24.44 & 1.149 & 0.016 & 0.003 & $\mathrm{~S}$ & 0.247 & $\mathrm{~S}$ \\
\hline & TN & 9.10 & 0.708 & 0.001 & 0.002 & NS & -0.033 & NS \\
\hline \multirow{2}{*}{$\begin{array}{c}\text { Pre- } \\
\text { Monsoon } \\
\text { (MAM) }\end{array}$} & TX & 32.89 & 0.759 & 0.005 & 0.002 & $\mathrm{~S}$ & 0.105 & NS \\
\hline & TN & 15.35 & 0.760 & 0.004 & 0.002 & NS & 0.039 & NS \\
\hline \multirow{2}{*}{$\begin{array}{c}\text { Summer } \\
\text { Monsoon } \\
\text { (JJAS) }\end{array}$} & TX & 32.05 & 0.867 & 0.007 & 0.003 & $\mathrm{~S}$ & 0.124 & NS \\
\hline & $\mathbf{T N}$ & 23.07 & 0.380 & -0.004 & 0.001 & $\mathrm{~S}$ & -0.291 & $\mathrm{~S}$ \\
\hline \multirow{2}{*}{$\begin{array}{c}\text { Post } \\
\text { Monsoon } \\
\text { (OND) }\end{array}$} & TX & 29.48 & 0.697 & 0.011 & 0.002 & $\mathrm{~S}$ & 0.301 & $\mathrm{~S}$ \\
\hline & TN & 10.03 & 0.758 & 0.010 & 0.002 & $\mathrm{~S}$ & 0.240 & $\mathrm{~S}$ \\
\hline
\end{tabular}

TX - Maximum Temperature; TN - Minimum Temperature;

S - Statistically significant at $5 \%$ significance level; NS - Statistically non-significant 
Trends in Rainfall and Temperature Patterns over North East India: Oza and Kishtawal
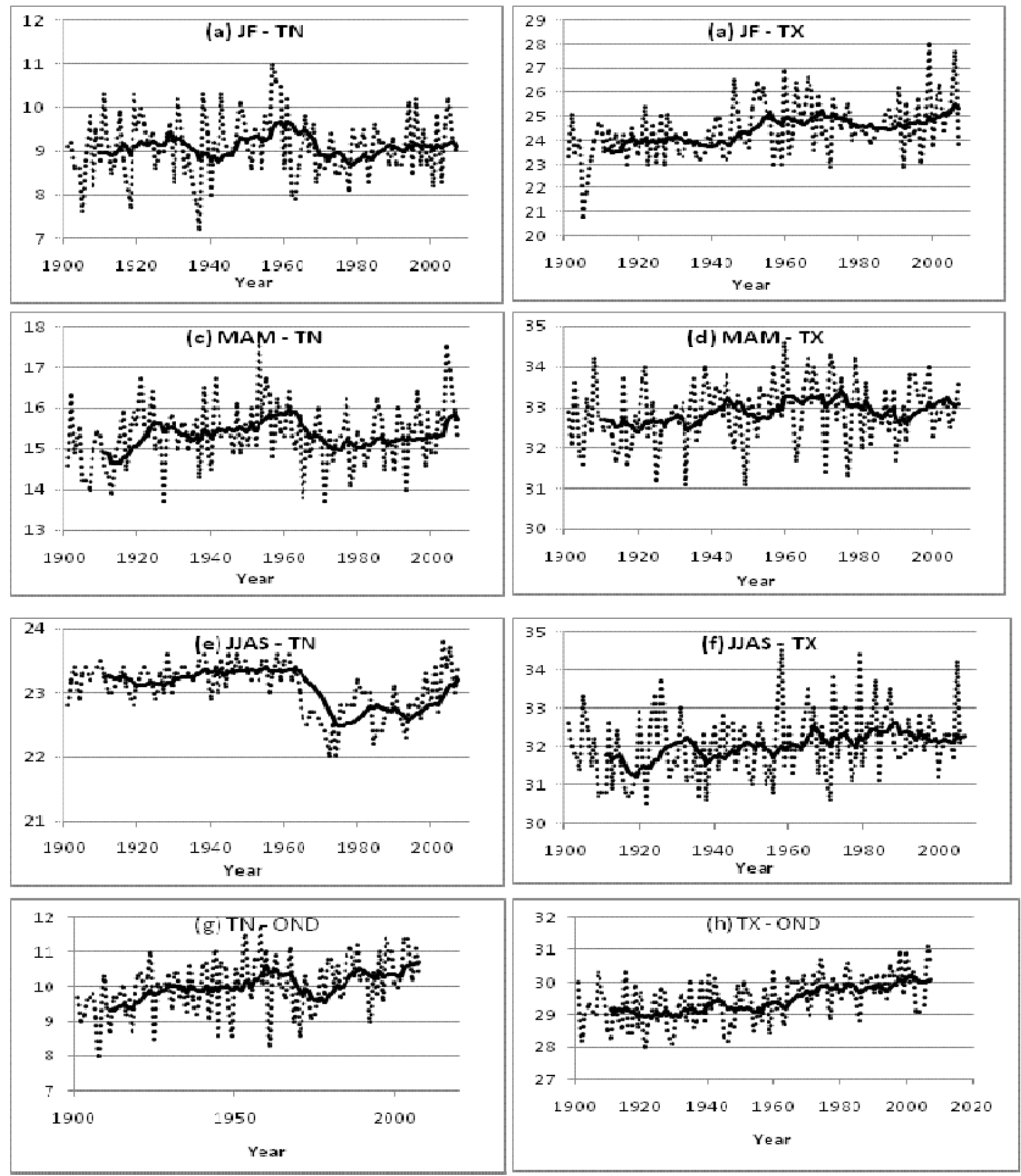

Fig. 4: Temporal pattern in minimum and maximum temperature during winter (a \& b), pre monsoon (c \& d), monsoon (e \& f) and post monsoon ( $\mathrm{g} \& \mathrm{~h}$ ) seasons in North East India (NEI) for the period 1901-2007. Dashed line represents original series and solid line represents 11 -year moving average data.

Basic statistics such as mean and standard deviation of smoothed series, the slope value, its standard error and statistical significance from OLS method and MKT statistic along with its 
Open access e-Journal

Earth Science India, eISSN: $0974-8350$

Vol. 7 (IV), October, 2014, pp. 90 - 105

http://www.earthscienceindia.info/

statistical significance are given in Table-4. Notice that variance of MKT statistic is function of length of series which is same for all the cases and hence not reported in the table.

Perusal of Table-4 reveals that long term behavior of TX by OLS method is increasing during all the four seasons at a rate of between 0.5 to $1.6^{\circ} \mathrm{C} / 100$-years. The increase is highest in winter months and lowest in pre-monsoon season. In MKT method, TX is significant for winter and post monsoon season and not significant during pre-monsoon and summer monsoon seasons. As far as TN is concerned, there was no significant change in winter and pre-monsoon season by OLS method. But in summer monsoon season minimum temperature showed decreasing trend $\left(0.4^{\circ} \mathrm{C} / 100\right.$-years $)$ and post monsoon season showed increasing trend $\left(1.1^{\circ} \mathrm{C} /\right.$ 100-years). The conclusions of OLS method were consistent with MKT analysis.

To detect short term behavior within the analysis period, a plot of Cramer's tau statistic was computed and plotted (Fig. 5). Since the length of series is long, the values beyond $+/-2$ can be considered as statistically significant. It can be seen that there is regularity of patterns. For example, closer inspection of Fig. 5(a) revels that TX was below long time average temperature in early time and dominated by above normal in recent past. Similarly, if one looks at Fig. 5(b), it is clear that there is a distinct point around 1967 from where behavior of TN in JJAS as changed from positive to negative for many years. To identify and high light such points of change in time, the years in which all the four seasons showed consistent behavior (i.e. had similar sign of tau statistic) were plotted (see Fig. 6). Fig. 6(a) clearly brings out that before 1955, the maximum temperature was below normal and increasing after, say, 1965. Similarly, from figure 6(b) it can be seen that before $1965 \mathrm{TN}$ was warmer and after 1967 it has become cooler. However, in recent past, TN appears to be going up.

To ascertain this hypothesis, Mann-Whitney non-parametric test for assessing the significance of a difference in central tendency of two series was applied with the break point at 1965. The null hypothesis is there in no change in central tendency for series (1901 -1965) and (1966-2007). Since previous analysis indicated possible increase in maximum temperature and lowering in minimum temperature, a series of temperature range $(\mathrm{TR}=\mathrm{TX}-\mathrm{TN})$ was also constructed and analysed. The mean and standard deviation of sum of ranks of smaller series (1966 - 2007) under the null hypothesis are 2268 and 156.748, respectively. The values of Ustatistic, the z-value and statistical significance for TX, TN and TR for the four seasons are given in Table-5.

From Table-5, it can be seen that post monsoon and winter months show statistically significant warming in maximum temperature. It is worth noting that during other two seasons, $\mathrm{z}$ - values are positive though not significant. The data also indicate lowering of minimum temperature in summer monsoon season. The temperature range TR showed statistically significant widening in winter, summer monsoon and post monsoon seasons but not in pre monsoon season. 

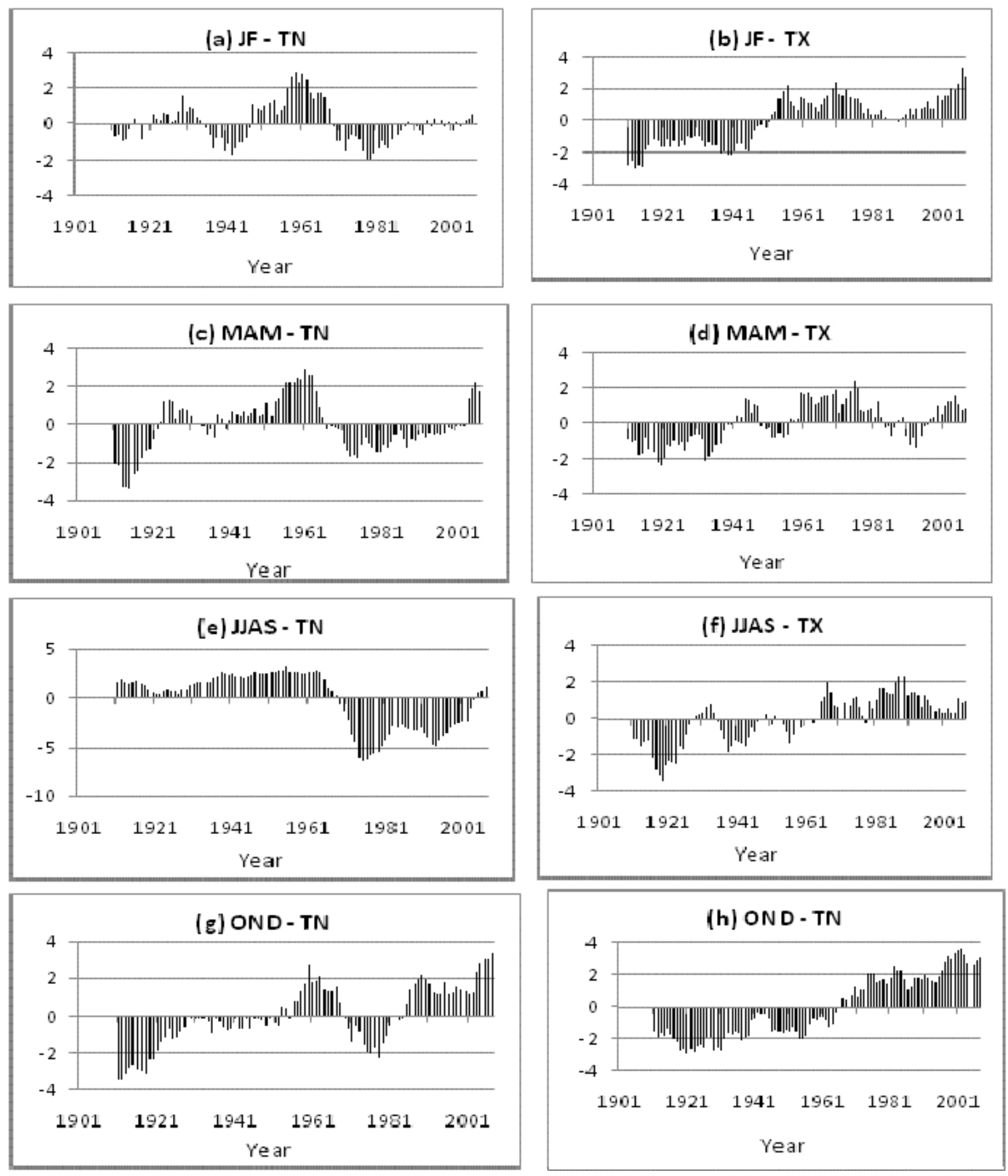

Fig. 5: Plot of Cramer's tau statistic (on y-axis) North East India (NEI) during winter (a \& b), pre monsoon (c \& d), monsoon (e \& f) and post monsoon ( $\mathrm{g} \& \mathrm{~h})$ seasons for the period $1901-2007$. 
Open access e-Journal

Earth Science India, eISSN: $0974-8350$

Vol. 7 (IV), October, 2014, pp. 90 - 105

http://www.earthscienceindia.info/
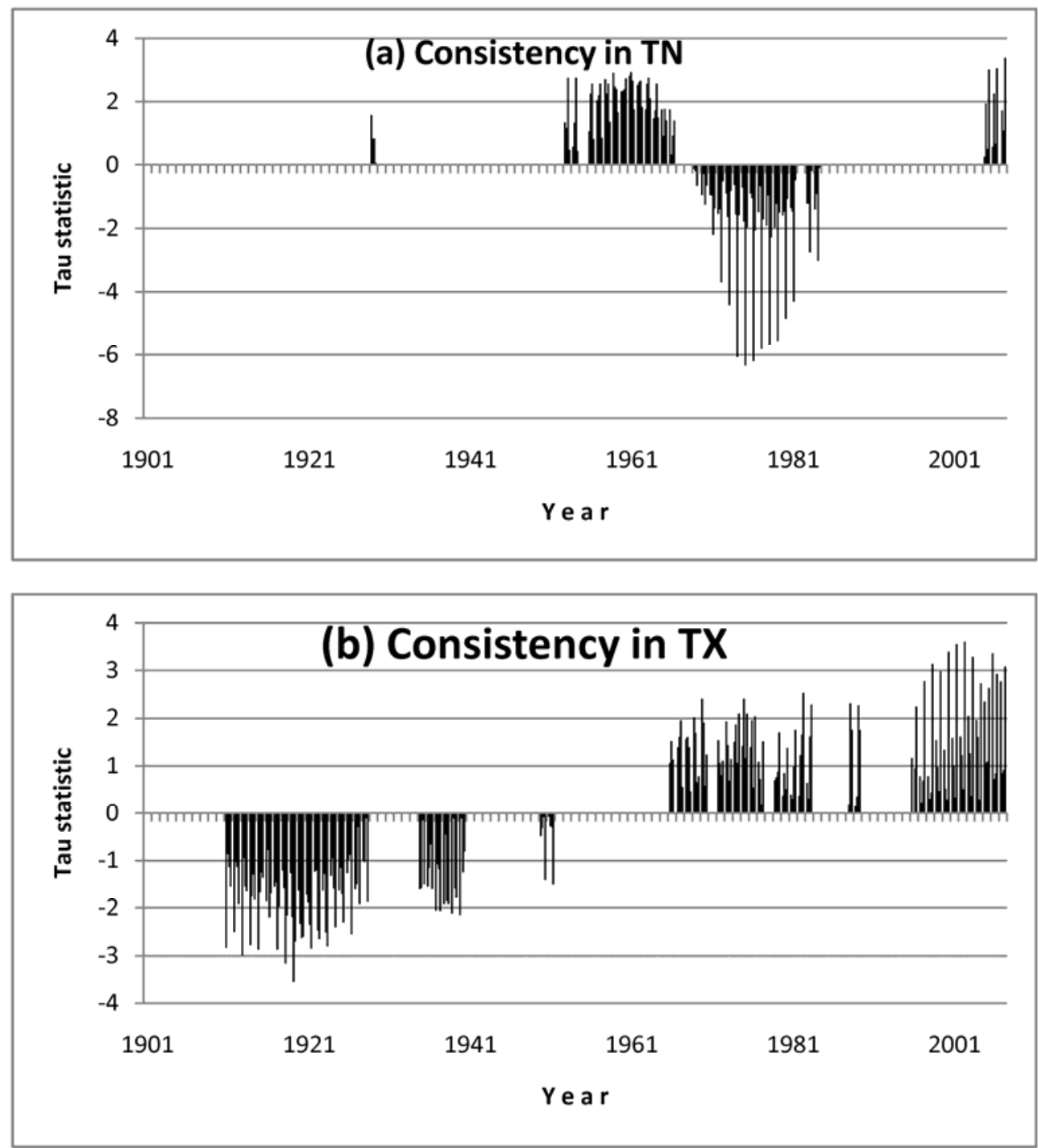

Fig. 6: Plot of Cramer's tau statistic when all the four seasons have consistent pattern (same sign of tau) North East India (NEI) for the period 1901 - 2007 (a) Maximum temperature (TX); and (b) Minimum Temperature (TN).

From the study carried out, it is very clear that decade of $1960-70$ is a point in time from where reversal of patterns in temperature and rainfall in North East India has taken place. It is not very clear if decreasing rainfall has led to increasing maximum temperature or it is vice versa. It is possible that both of these phenomena may be result of some bigger atmospheric circulation pattern or changing land cover such as decrease in Arctic ice cover during 1960s. Another possible cause could be increase in agricultural area and intensification of agriculture, particularly in Indo-Gangetic plains of India, as a result of conscious effort to improve irrigation 
facilities under first few five years plans after independence and onset of green revolution. These hypotheses need to be investigated and confirmed.

Table-5: The Mann-Whitney test statistic (U) for TX and TN during four seasons in NEI.

\begin{tabular}{|c|c|c|c|c|}
\hline Season (Months) & Variable & $\mathbf{U}$ & $\mathbf{Z}$ & $\begin{array}{c}\text { Statistical } \\
\text { Significance }\end{array}$ \\
\hline \multirow{4}{*}{ Winter (JF) } & TX & 2732 & 2.960 & $\mathrm{~S}$ \\
\cline { 2 - 5 } & TN & 2040 & -1.455 & $\mathrm{NS}$ \\
\cline { 2 - 5 } & $\mathbf{T R}$ & 2719 & 2.877 & $\mathrm{~S}$ \\
\hline \multirow{2}{*}{$\begin{array}{c}\text { Pre-Monsoon } \\
\text { (MAM) }\end{array}$} & TX & 2439 & 1.091 & $\mathrm{NS}$ \\
\cline { 2 - 5 } & TN & 2119 & -0.951 & $\mathrm{NS}$ \\
\cline { 2 - 5 } & TR & 2495 & 1.448 & $\mathrm{NS}$ \\
\hline \multirow{3}{*}{$\begin{array}{c}\text { Summer Monsoon } \\
\text { (JJAS) }\end{array}$} & TX & 2519 & 1.601 & $\mathrm{NS}$ \\
\cline { 2 - 5 } & TN & 1203 & -6.794 & $\mathrm{~S}$ \\
\cline { 2 - 5 } & TR & 2875 & 3.872 & $\mathrm{~S}$ \\
\hline \multirow{2}{*}{$\begin{array}{c}\text { Post Monsoon } \\
\text { (OND) }\end{array}$} & TX & 2979 & 4.536 & $\mathrm{~S}$ \\
\cline { 2 - 5 } & TN & 2510 & 1.544 & $\mathrm{NS}$ \\
\cline { 2 - 5 } & TR & 2612 & 2.195 & $\mathrm{~S}$ \\
\hline
\end{tabular}

\section{Conclusions}

From the present analysis it can be concluded that:

1. There is a decreasing trend in Indian summer monsoon rainfall at all India level as well as in NEI. Even in NEI, the rate of decrease is steeper as one goes towards east.

2. Maximum temperature in NEI is increasing during all the four seasons at a rate of between 0.5 to $1.60 \mathrm{C} / 100$-years. The increase is highest in winter months and lowest in pre-monsoon season.

3. No consistent direction of change emerged in the analysis of minimum temperature data.

4. Decade of 1960 - 70 comes out as a critical time point from where the reversal of trend in climatic variables is noticeable.

Acknowledgement: The authors are thankful to Director, SAC and DD, EPSA for their guidance and encouragement and to GD-AOSG for his valuable comments, suggestions and fruitful discussions. Authors sincerely wish to acknowledge Indian Institute of Tropical Meteorology (IITM) for hosting high quality weather data over India. Thanks are also due to reviewers for their valuable suggestions. 


\section{References}

Abaje, I. B, Ati O. F. and Iguisi, E.O. (2012) Recent trends and fluctuations of annual rainfall in the SudanoSahelian ecological zone of Nigeria: Risks and opportunities. Journal of Sustainable Society, v. 1(2), pp. 44-51.

Alexander, L. V., Zhang, X., Peterson, T. C., Caesar, J., Gleason, B., Klein Tank, A. M. G., Haylock, M., Collins, D., Trewin, B., Rahimzadeh, F., Tagipour, A., Rupa Kumar, K., Revadekar, J., Griffiths, G., Vincent, L., Stephenson, D. B., Burn, J., Aguilar, E., Brunet, M., Taylor, M., New, M., Zhai, P., Rusticucci, M. and Vazquez-Aguirre, J. L. (2006) Global observedchanges in daily climate extremes of temperature and precipitation. Journal of Geophysical Research, v. 111:D05109. DOI: 10.1029/2005JD006290.

Arora, M., Goel, N. K. and Singh. P. (2005) Evaluation of temperature trends over India. Hydrol. Sci. J., v. 50, pp. $81-93$.

Deka, R. L., Mahanta, C. and Nath, K. K. (2009) Trends and fluctuations of temperature regime of North East India. ISPRS Archives XXXVIII-8/W3 Workshop Proceedings: Impact of Climate Change on Agriculture, pp. $376-380$.

Dhorde, A., Dhorde, A. and Gadgil, A. S. (2009) Long-term temperature trends at four largest cities of India during the twentieth century. J. Ind. Geophys. Union, v.13(2), pp.85-97.

Essenwanger, O. M. (1985) World survey of climatology. General climatology IB. Elsevier, Amsterdam.

Ganguly, N.D. and Iyer, K.N. (2009) Long term variation of surface air temperature during summer in India. International Journal of Climatology, v. 29(5), pp. $735-746$.

Gibbons, R.D. and Coleman, D. E. (2001) Statistical methods for detection and quantification of environmental contamination. Published by Wiley-IEEE.

Hamed, K.H. and Rao, A.R. (1998) A modified Mann-Kendall test for auto-correlated data. Journal of Hydrology, v. 204, pp.182-196.

Hirsch, R.M., Helsel, D.R, Cohn, T.A. and Gilroy, E.J. (1992) Statistical analysis of hydrologic data. In: D.R. Maidment (ed.) Handbook of Hydrology, McGraw-Hill, New York.

IPCC (2008) Climate change and water. Technical paper of the Intergovernmental Panel on Climate Change [Bates, B.C., Kundzew, Z. W.,Wu, S., and Palutikof, J.P.(Eds.)], IPCC Secretariat, Geneva. 210 p.

Kadiolgu, M. (1997) Trends in surface air temperature data over Turkey. Intl. J. Climatol., v. 17, pp. 511-520.

Kite, G. W. (1988) Frequency and risk analysis in hydrology. Water Resources Publications. Colorado, USA.

Klein Tank, A. M. G. and Können, G. P. (2003) Trends in indices of daily temperature and precipitation extremes in Europe, 1946-99. J. Climate, v. 16, pp. 3665-3680.

Kothawale, D.R. and Kumar, K. R. (2005) On the recent changes in surface temperature trends over India, Geophys. Res. Lett., v. 32, L18714, doi:10.1029/2005GL023528.

Kripalani, R. H. and Kulkarni, A. (1996) Assessing the impacts of El Niño and Non-El Niño-related droughts over India. Drought Network News (October 1996). http://digitalcommons.unl.edu/droughtnetnews/24.

Kumar, K.R. and Hingane, L.S. (1988) Long tern variations of surface air temperature at major industrial cities of India. Climate Change, v. 13 (3), pp. $287-307$.

Kumar, K.R., Krishankumar, K. and Pant, G.B. (1994) Diurnal asymmetry of surface temperature trends over India. Geophys. Res. Lett., v. 21, pp. 677-680.

Mirza, M.Q. (1997) Hydrological changes in the Ganges system in Bangladesh in the post-Farakka period. Hydrological Sciences, v. 42 (5), pp. $613-631$

Pant, G.B. and Kumar, K.R. (1997) Climate of south Asia. John Wiley \& Sons, Chichester, 320p.

Piechota, T.C., and Garbrecht, J.D. (2006) Climate variability and climate change. Environmental and Water Resources Institute of the American Society of Civil Engineers, United States of America, pp. 3-18.

Pramanik, S.K., and Jagannathan, P. (1954) Climatic changes in India rainfall. Indian J. Meteorol. Geophys., v. 4, pp. 291-309.

Sneyers, R. (1990) On the statistical analysis of series of observations. WMO Technical Note 143. WMO No. 415, TP- 103, Geneva, World Meteorological Organization, 192 p.

Tabari, H., Somee, B. S., and Zadeh, M. R. (2011) Testing for long-term trends in climatic variables in Iran. Atmospheric Research, v. 100, pp. 132-140. 
Trends in Rainfall and Temperature Patterns over North East India: Oza and Kishtawal

Wagholikar, N. K., Sinha Roy, K. C., Sen, P. N. and Kumar, P. P. (2014) Trends in seasonal temperatures over the India region. Journal of Earth System Science, v. 123(4), pp $673-687$.

Wilcox, R. R. (1998) A note on the Theil-Sen regression estimator when the regressor is random and the error term is heteroscedastic. Biometrical Journal, v. 40, pp. 261-268.

WMO (1966) World Meteorological Organization: Climatic change. WMO Tech. Note No. 79, WMO No. 195-TP100, Geneva.

(Received: 14.05.2014; Accepted: 20.10.2014) 